\title{
Bad Bank is Actually a Good Idea
}

\author{
S. Prasanth ${ }^{* 1}$, Dr. S.Sudhamathi ${ }^{2}$ \\ ${ }^{1}$ Ph. D. Scholar, Alagappa Institute of Management, Alagappa University, Karaikudi, Tamilnadu - 630002 \\ E-mail id: anbayprasanth@gmail.com \\ ${ }^{2}$ Assistant Professor, Alagappa Institute of Management, Alagappa University, Karaikudi, Tamilnadu- 630002
}

\begin{abstract}
This article demonstrates the effect of bad loans in India which was developed recently by the Indian Finance Minister. Bad banks operate like a concept in the domestic debt sector where the amount of domestic debt is high and even the market has enough scale to bear enough price-discovery and market-making. there was a proposal made to the government, to merge the NPA portfolio with a new establishment known as an Asset Rehabilitation Corporation (ARC), that would purchase the principal of the Non-performing Assets (NPA) portfolio at a book valuation (not market value) and these accounts would be taken over by the new company to manage the portfolio of the new command (which will be established with a capital of Rs 10,000 crore). The government says that it is intervening to mitigate potential damages that the banks could suffer as a result of the provisioning for non-performing assets and recapitalisation that the government (as a majority investor of most PSBs) may be required to invest on. With the forthcoming Union budget's planning an outpouring of clamour and market demand is being felt to set up a 'poor bank' to sweep bad debts.
\end{abstract}

Keywords — Non-performing Assets; Asset Rehabilitation Corporation; Insolvency and Bankruptcy Code; Bank.

\section{Introduction}

Think of a bank or non-bank loan as a place to go and get money and keep paying it back as much as you desire before the final balance of each payment. On the liability side, there's the establishment of legislation under which banks are allowed to increase their deposits from the economy. With the investment, they can use that as debt redemption to keep chugging along. On the benefits side, though, the banks can charge comparatively abysmally low interest rates and sell dangerous loans to lower-income people and households with marginal credit scores. Anything that is not a performing commodity is very much a part of this sector. If any of these variables contributed to the stress experienced by an organisation, it is possible that the stress was caused by a shift in the industry cycle, poor management planning, or the malicious purpose of the organization's promoter (which the law provides to be dealt with differently). As this event has spread, this outbreak has been unprecedented in its fury and has both disrupted the world economy and has shattered local feelings.

The Insolvency and Bankruptcy Code, 2016 (IBC), the bankruptcy law of India requires debtors, creditors, and the businesses themselves to apply for an especially troubled company to be sold to another group of promoters. From the IBC's view, the main thing being that the bank was in charge and ownership of the property was in the debtor's control. Because of the ongoing coronavirus outbreak, the government will not give approval for another IBC until March 31, 2021. The banking regulator RBI had placed a three months moratorium on its customers to make sure they have access to their short term and long term assets.
The ban has been extended for an additional three months. This issue of moratorium is presently under consideration by the Supreme Court (SC), and the outcome might have implications for the provisioning of assets on the balance sheet of the whole banking and financial industry if the case is successful. However, RBI has not been as accommodating with those who lend money to these people. This has made it impossible for lenders to settle their debts without receiving from their borrowers due to lack of payment.

The KV Kamath committee, consisting of RBI staff, built a way to restructure lenders' exposure to certain industries to remain in line with certain financial ratios. Bankers have been concerned that any judgement on a case of writing down the debt might potentially attract the other three letters: the judiciary, the CVC, the CBI, and the CAG. It would be helpful to note the other " $\mathrm{C}$ " beginning with the letter "C" which means 'Cabinet'. It would be useful to benefit from the security offered by the Cabinet's decision to enact proper and revised guidelines/laws to regulate the banking industry. This would be a game-changer that would encourage bankers to be able to make business decisions without being restrained by bureaucracy, which would allow financial institutions like the central bank to take all new commercial decisions with complete governance norms.

\section{Bad Bank}

A "bad bank" is a bank that sells the distressed debts made by other lenders and financial institutions to alleviate the collections of cash. The bad assets are fixed over time as

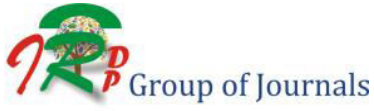


bad assets are then resolved. When the banks are relieved of the NPA pressure, they will be able to find newer loans, which they will see as more lucrative. A financial business should be owned by banks with the most non-performing assets."Back from the dead" is how international media today describes the Bank of Cyprus after its resolution. Although market perception and financial results are improving considerably, there is still a "nightmare haunting" BoC's credibility and performance: the big scale of Non- Performing Loans. The case storey recounts all of the significant events that occurred during and after the tumultuous crisis era, as well as the steps taken by the CEO of $\mathrm{BoC}$ to address the bad debt problem and the premise that a "bad bank" would be established.

According to NCÜ (2017), a bad bank is a legal entity established with the goal of separating stressed assets held by a conventional bank from the bank's performing assets and other assets. As previously indicated, the separation referred to above is effected by the transfer of stressed assets from the regular bank to the bad bank. Upon completion, the stressed assets are removed from the regular bank's balance sheet, after which the bank is recapitalized and the process is repeated. It will then be possible for the normal bank to concentrate on its regular business activities without being distracted by the stressed assets. The bad bank is entrusted with the job of managing and/or liquidating the stressed assets that have been acquired by the institution. In the banking industry, a "good bank" is defined as a financial organisation that has successfully removed toxic and stressed assets from its balance sheet.

\section{Objectives}

The main objectives of creation of the bad bank are,

- To improve the health of Indian banks' balance sheets;

- To allow banks to achieve the appropriate level of capital adequacy by raising new capital from the market;

- To increase loan growth in order to spur investment and, eventually, economic growth. In essence, a bad bank would assist Indian banks in reducing their losses and allowing them to focus on their primary business of lending. Let's take a closer look at the situation.

\section{Historical Examples of Bad Banks}

Bad banks emerged in the late 1980s as a result of a crisis in the banking sector of the United States of America, and they were more than just a theory at the time. A number of banks were on the verge of failure or insolvency at the time, owing to the precipitous decline in real estate and oil prices (Bleier, 2008). Mellon Bank, which is located in Pittsburg, Pennsylvania, was the most severely affected. That particular bank was incurring losses on a consistent basis and needed to be recapitalized. As a result, Mellon Bank established a new bank, known as the Grant Street National Bank, for this purpose (GSNB). In contrast to a traditional bank, GSNB did not accept deposits and then lend the money collected. The formation of GSNB was intended to facilitate the transfer of Mellon Bank's hazardous assets to it (McKinsey\& Company, 2003). Later, the GSNB would liquidate those hazardous assets, and then it would go into liquidation itself. The hazardous assets of Mellon Bank, which had an original value of $\$ 1.4$ billion, were transferred to GSNB for a depressed book value of $\$ 640$ million, resulting in a net gain of $\$ 640$ million. The majority of the funds for this transaction came from a public offering of extendable pay-through notes, as well as Mellon Bank's shareholder dividends. (The shareholders of Mellon Bank got GSNB's shares in exchange for the value of their dividend.) GSNB, which was established in 1988, liquidated all of the hazardous assets that were transferred to it and was officially declared inactive in July 1995 (Bleier, 2008). Mellon Bank, on the other hand, began making profits within roughly a year following the establishment of the GSNB (McKinsey\& Company, 2003). Following the success of the Mellon Bank case, the good bank-bad bank strategy has been implemented both in the United States and in other nations as a result of its success. Because of the success of GSNB, the United States government decided to form an asset management firm, which was later renamed the Resolution Trust Corporation. This organisation was tasked with the responsibility of disposing the stressed assets of banks that had been deemed bankrupt by the Office of Telecommunications and Information Technology. This corporation was involved in the liquidation of stressed assets totaling $\$ 394$ billion that developed as a result of the saving and loan crisis of the 1980s (Schäfer \& Zimmermann, 2009), which occurred in the early 1990s. This poor bank resolution procedure, on the other hand, came at a cost to the American taxpayer of \$ 124 billion (Curry \& Shibut, 2000). Japanese banks have used the good bank-bad bank approach to restructure their bad loans in order to reduce their bad debts. In 1992, the Banker's Association of Japan established the Credit Cooperative Purchasing Company, which was designated as a bad bank (CCPC). This firm acquired and serviced the stressed assets of Japanese banks when they became insolvent (Bleier, 2008). A loan in the amount of the selling value was extended by the banks who sold the stressed assets at a reduced price to CCPC itself in order to finance the transaction. A real estate property and other assets that had been pledged as security for the stressed assets were later sold by the CCPC, with the proceeds going towards repaying a loan made available to it by a bank that had sold the stressed assets to it (Taniuchi, 1997). To deal with the bad loan problem in their respective banking sectors, many European nations have effectively implemented different shades of the good bank - bad bank solution in their respective banking sectors. Sweden was

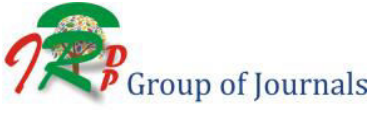


the site of the establishment of the first bad banks in Europe. According to Schafer and Zimmermann (2009), the Swedish government established two bad banks under the names Securum and Retriva. Nordbanken, a commercial bank, was forced to close its doors in 1992, and Securum was formed to take over its stressed assets. It was possible for Securum to finance this acquisition partially through a loan from Nordbanken and partly by an injection of public stock (Repousis, 2017). Retriva, which was created about the same time to take over the stressed assets of Gota Bank, was also established (Ingves\& Lind, 1996). After Gota Bank's assets were liquidated, Nordbanken was able to buy the remaining decent assets (Repousis, 2017). The tax payer incurred a significant loss as a result of the bailout package; however, the loss was recouped by the end of 2007 as a result of earnings from dividends, stock sales, and other sources (Schäfer \& Zimmermann, 2009). The two bad banks, for their part, were successful in liquidating the stressed assets that they had taken over (Repousis, 2017). BIH was established in 2006 to separate the stressed assets of a bank known as Berliner Bankgesellschaft (Schäfer \& Zimmermann, 2009). BIH is a bad bank in Germany that was established in 2006 to separate stressed assets of a bank known as Berliner Bankgesellschaft (Schäfer \& Zimmermann, 2009). However, when a more severe financial crisis hit Germany in 2008-09, the German Federal Legislature adopted legislation in July 2009 requiring the provision of a good bank-bad bank solution that placed a minimal cost on the German tax payer. The aforementioned statute established two distinct bad bank models for private and state banks, respectively. In order to accommodate private banks, German law established a special purpose company model. The aforementioned concept saw private banks transfer their stressed assets to these special purpose companies at book value in exchange for a tax deduction. As part of the consideration for transferring the stressed assets, these special purpose organisations issued bonds to the transferring bank equal to 90 percent of the book value of the stressed assets. These bonds were backed by a government-sponsored organisation known as the Special Fund for Financial Market Stabilization (SFFS) (SoFFin).

\section{Bad Loans At A Glance}

Risk exists in every industry, but it is particularly prevalent in banking. Indian banks have been experiencing large losses as a result of a variety of factors including the economic downturn, delayed projects, cost overruns, difficulties in obtaining licences, and land acquisition issues, among others.

A new report from the Reserve Bank of India, titled "Developments and Development Report 2020," shows that gross non-performing assets (GNPAs) held by Indian banks increased to 8.2 percent at the end of the report year (March 31, 2020) from 9.1 percent at the end of the previous year. PSBs' research and development (R\&D) investment was Rs. 6.78 lakh crore as of March 31, 2020, according to the company.

The fast expansion in credit over the period 2005-12, along with the absence of a comprehensive credit assessment process and inadequate loan management procedures, are the major causes for the large number of bad loans during the later portion of this era of history. Overall gross non-performing assets (GNPAs) of Indian banks declined marginally from March 2019 to March 2020, although restructuring of normal advances grew from 0.36 percent to 0.43 percent of GNPAs, signalling a period of incipient stress in the market during this time period.

The contribution of GNPAs would have been larger if the RBI had not imposed an asset quality halt and the Covid-19 relief mechanism had not been in place at the time. The Reserve Bank of India (RBI) has issued a warning that the asset quality of the Indian banking sector would deteriorate dramatically in the near future. In addition to recapitalization, a recent Economic Report recommends that balance sheets be cleaned up. Because, it would be controlled by the government, as has been suggested, the bad bank would be more powerful than the existing Asset Restoration Firms. When non-performing assets (NPAs) are transferred to the bad bank, public sector banks will no longer be forced to rely on greater provisions but will instead have ready access to capital in the business. This is due to the significant increase in discount rates from 30 to 60 percent of the book value of the bad loan to the upfront cash fee of 15 percent levied by the ARCs, as well as the fact that the bad bank was established at a reasonable time.

Banks in India have been slow to sell poor assets to asset recovery companies (ARCs) because the ARCs have been unwilling to absorb the liabilities of the banks.

\section{The Way Forward}

In the Indian banking system, a vicious cycle has developed, with high non-performing assets (NPAs) and inadequate capital sufficiency both leading to low profitability levels. The lack of expansion in credit leads to an increase in non-performing loans (NPAs). Despite the fact that banks are specialists in lending, they are not experts in managing massive stressed assets; they lack both the necessary degree of legal competence and the enabling environment in which to recover non-performing assets.

Previously, banks had to concentrate on capacity building and re-skilling of their in-house employees in

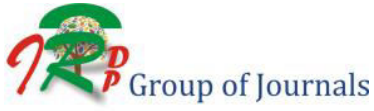


areas such as loan rehabilitation, risk management, and so on in order to remain competitive.

\section{Conclusion}

The government, on the other hand, is prepared to privatise public-sector businesses, but the prices may be below market value. An ill-managed bank looks to be one of the better of the poor alternatives available to the public at large. However, if an efficient business model for the bad bank can be established, it has the potential to address issues like as inadequate capital and the double balance sheet problem in India, which are now being addressed. In order to assure the success of bad bank, it is necessary to pick relevant institutions based on criteria that are recognised, professional, and independent. However, because of the off-balance sheet risk and the legal obstacles, it is difficult to form a bad bank.

\section{Reference}

[1] Gabriel Brenna; Thomas Poppensieker \& Sebastian Schneider (December 2009). "Understanding the bad bank". McKinsey \& Company. Retrieved 8 May 2014.

[2] Cade, Eddie (2013). Managing Banking Risks: Reducing Uncertainty to Improve Bank Performance. Routledge. pp. 141-142. ISBN 9781135952143.

[3] Morning Edition. "Why A 'Bad Bank' Is A Good Idea". NPR. Retrieved 10 April 2013.

[4] Fitzpatrick, Dan (8 August 2008). "The Return of 'Good Bank-Bad Bank'". The Wall Street Journal. Retrieved 8 May 2014.

[5] "Mellon Will Shift \$1 Billion in Bad Loans : Forming Entity to Help Improve Ailing Finances - Los Angeles Times". Articles.latimes.com. 26 July 1988. Retrieved 4 August 2014.

[6] Moore, Heidi N. (8 September 2008). "The 'Bad Bank' Experience: Lessons From Mellon-Grant Street - Deal Journal - WSJ". Blogs.wsj.com. Retrieved 4 August 2014.

[7] Bergström, Clas; Peter Englund; Per Thorell (May 2003). "Securum and the way out of the Swedish Banking Crisis" (PDF). Summary of a Report Commissioned by SNS - Center for Business and Policy Studies. Archived from the original (PDF) on 21 February 2014.

[8] Hagan, Sean; Christopher Towe (17 April 2009). "An overview of bank Insolvency" (PDF). IMF Staff Papers.

[9] Ingves, Stefan (September 2006). "Finansiellakriseriettinternationelltperspektiv". Riksbanken.

[10] Dougherty, Carter (22 January 2009). "Sweden's fix for bank: nationalize them". The New York Times.

[11] Öncü, T. S. (2017, March 11). Bad Bank Proposal for India A Partial Jubilee Financed by ZeroCoupon Perpetual Bonds. Economic \& Political WEEKLY, LII(10), 12-15.

[12] Bleier, M. E. (2008). From 'Bad' Bank to 'Good'. Pittsburg: reedSmith.com.

[13] McKinsey\& Company. (2003). Managing Successful Bank Restructuring: The Mellon BankStory. Emerging Markets Financial Institutions Group.

[14] Schäfer, D., \& Zimmermann, K. (2009, June). Bad Bank(s) and Recapitalization of the Banking Banks. IZA Policy Paper No. 10. Bonn, Germany: Institute for the study of Labor.

[15] Curry, T., \& Shibut, L. (2000). The Cost of the Savings and Loan Crisis: Truth and Consequences. FDIC Banking Review, 13, 26-35.

[16] Taniuchi, M. (1997, May). Recent Developments in Japan's Financial Sector -- Bad Loans and Financial Deregulation --. Discussion Paper No. 76. Tokyo, Japan: http://www.esri.go.jp.
[17] Repousis, S. (2017, July). "Bad Bank" Strategy in Greek Banking Sector and Receivables from Banks under Liquidation. International Research Journal of Finance and Economics (162), 121-128. 